\title{
Critiquing and Joining Intersections of Disaster, Conflict, and Peace Research
}

\author{
Laura E. R. Peters ${ }^{1} \cdot$ Ilan Kelman ${ }^{2,3}$
}

Published online: 10 July 2020

(C) The Author(s) 2020

\begin{abstract}
Disaster research, conflict research, and peace research have rich and deep histories, yet they do not always fully intersect or learn from each other, even when they investigate if and how disasters lead to conflict or peace. Scholarship has tended to focus on investigating causal linkages between disaster (including those associated with climate change) and conflict, and disaster diplomacy emerged as a thread of explanatory research that investigates how and why disaster-related activities do and do not influence peace and conflict. However, definitive conclusions on the disaster-conflict-peace nexus have evaded scientific consensus, in part due to conceptual, methodological, and interpretive differences among studies. This article highlights that this nexus would benefit from a more robust engagement with each field's foundational research that explores beyond binary and crude distinctions. Examples are concepts of destructive and constructive conflict; direct, structural, and cultural violence, and their relationships to vulnerability; negative and positive peace; and the ideals and realities of peacebuilding and conflict transformation. This article demonstrates how integrated scholarship could open up and advance new lines of questioning, with implications for developing coherent research, policy, and practice. The article
\end{abstract}

Laura E. R. Peters

peterlau@oregonstate.edu

1 College of Earth, Ocean, and Atmospheric Sciences, Oregon State University, Corvallis, OR 97331, USA

2 Institute for Risk and Disaster Reduction, and Institute for Global Health, University College London,

London WC1E 6BT, UK

3 University of Agder, 4630 Kristiansand, Norway concludes by offering recommendations for how to better connect disaster, conflict, and peace research.

Keywords Climate change - Conflict research - Disaster diplomacy $\cdot$ Disaster risk reduction $\cdot$ Peace research

\section{Background}

Disaster researchers have spent decades challenging strong narratives in academic literature and popular media that argue that disasters result in conflict, including a breakdown in social order, panic, looting, and violence (Quarantelli 1954; Dynes and Quarantelli 1968; Quarantelli and Dynes 1976; Xu et al. 2016; Brzoska 2018; Nogami 2018). This narrative manifests in numerous ways including claims that (1) hazard influencers such as climate change will incite war (challenged by Buhaug 2010) and mass migration (challenged by Baldwin et al. 2019), and that (2) command-and-control approaches should be employed after a disaster to stop survivors from running rampant (challenged by Alexander 2020). Another major implication of the discourse that disasters cause conflict is that it securitizes disaster-related concerns (as deconstructed by Hartmann 2010 and Nicholson 2014) and promotes topdown interventionist approaches to stymie the assumed ripple effects of instability (challenged by Alexander 2020).

Nevertheless, just because disasters and hazards do not inevitably create or drive different forms of conflict does not mean that they necessarily reduce conflict or create peace. Studies of cooperation and collaboration induced by hazards and disasters show mixed results without definitive conclusions about disasters as peacemakers or peacekeepers (Comfort 1990; Enia 2008; Régnier 2011; Kreutz 2012; 
Acuto 2014; Dany 2018). From such bodies of literature, one subset termed "disaster diplomacy" has emerged that examines how and why disaster-related activities-before, during, and after disasters-do and do not affect different forms of peace and conflict (Kelman 2012, 2016). The suggestion overall from disaster diplomacy thinking is that disasters can provide short-term opportunities to resolve or create violent and non-violent conflict, but pursuing those opportunities or not is determined mainly by pre-disaster conditions. These analyses further demonstrate the wide separation between much disaster-related work, much conflict-related work, and much peace-related work. Scholarship on climate change has now generated yet another body of nearly independent research and discourse on conflict (although not much on peace), typically without drawing on the lessons and foundations of prior work (Brzsoka 2018 is an exception).

This article provides a critiquing overview of how intersections between disaster, conflict, and peace research could be improved, with particular attention given to disaster diplomacy approaches as one possible bridge among them. The following two sections examine how disaster, conflict, and peace research do and do not interlink, through the disaster-conflict nexus (Sect. 2) and through disaster diplomacy (Sect. 3). Section 4 explores ways of improving the links through commonalities of interpretations and misapprehensions, as well as the ubiquitousness of politics and power, leading to possibilities for better connections. Finally, this article's contribution is summarized, and recommendations are made in order to provide opportunities to better connect disaster, conflict, and peace research.

\section{The Disaster-Conflict Nexus}

From the beginning, disaster research has been strengthened by an interest in understanding conflict. Early disaster studies in the 1940s were supported by U.S. military organizations compelled by a desire to anticipate the conditions and social responses associated with war-related disasters (Quarantelli 1987). This research agenda later shifted to investigating the causal relationships between disasters and conflict—empirical research that established these linkages surfaced in the 1990s and became more rigorous in the 2000s (Nardulli et al. 2015). The 2000s also saw peace emerge as a phenomenon of more direct interest when "disaster diplomacy" research began to explore to what extent and how disasters and disaster-related activities influence peace and cooperation (Kelman and Koukis 2000; Kelman 2012) (see Sect. 3).

As these varied research agendas on disaster, conflict, and peace have matured, they have identified and investigated a multitude of relationships between these phenomena, revealing complexity, nonlinearity, and dynamism. Numerous intersecting factors reinforce, exacerbate, or intervene in disaster-conflict-peace relationships and influence a wide breadth of possible, but far from certain, outcomes. From a policy standpoint, this trend moves away from considering disaster and climate change risks as national or human security threats and moves toward recognizing disaster risks as complex systems of risk, alongside other risks such as conflict and fragility, economic shocks, and health crises (UNDRR 2019) that affect the "living fabric" of communities (Sarmiento et al. 2018, p. 40). Despite the long-standing discussions on such approaches, efforts to understand this interconnectivity do not always fully account for these deep and broad understandings.

A cohort of research on disaster, climate change, and conflict concludes, for example, that disasters and the effects of climate change (including changes to weatheroften expressed through temperature, precipitation, and storm parameters-sea levels, and ocean acidity) heighten the risk of conflict onset, intensity, or duration. The premise of this research agenda often builds on early neoMalthusian environment-conflict research conducted by Homer-Dixon (1994, 1999), who influentially claimed that environmental scarcity (or "eco-scarcity")—driven by population growth or increased natural resource consumption, environmental degradation, and/or unequal distribution of resources-can lead to social instability and conflict. When combined with governance issues and instability, eco-scarcity may even contribute to state failure (Kahl 2006).

Research along this thread has connected disasters to an increased risk of conflict onset and intensity in numerous ways. Several studies have found that climate "shocks" and disasters are linked to an increased risk of conflict onset (Nel and Righarts 2008; Hendrix and Salehyan 2012), from international conflict (Nelson 2010) to local discord (Carroll et al. 2006), conflict intensity (Gawande et al. 2017), repressive (Wood and Wright 2016) or manipulative regime tactics (Schneider and Hwang 2014), political regime destabilization or change (Flores and Smith 2013; Carlin et al. 2014; Venugopal and Yasir 2017), and gender-based violence (Fisher 2010). Other studies illustrate that the eco-scarcity hypothesis does not fully explain linkages from the environment to conflict. For example, not only water scarcity and drought are sometimes positively correlated with violence, but also shortterm water abundance (Salehyan and Hendrix 2014), extreme rainfall deviations in either direction (Raleigh and Kniveton 2012), and interannual rainfall variability (Hendrix and Glaser 2007). 
Consequently, irrespective of correlations, understanding causation requires further work, including understanding the role of local contexts. Despite a range of possible explanations for these relationships, the body of research on disasters and conflict does not present uncontested statistical relationships or well-defined explanatory mechanisms. Berrebi and Ostwald (2011) conducted a statistical study showing that disasters with more fatalities result in a higher risk for terrorism and associated fatalities, while Bhavnani (2006) demonstrated that disasters with more survivors resulted in a higher risk of conflict due to disaster-related grievances.

Likewise, climate change has been cited as playing a central role in precipitating several high-intensity civil armed conflicts and humanitarian crises, but not without controversy. Kelley et al. (2015) propelled a debate on the role of anthropogenic climate change-induced droughtmediated through crop failure and large-scale migration to cities-in inciting the Syrian Conflict in 2011. Yet, other research has claimed that the drought did not play a central role in the Syrian Conflict (Selby et al. 2017) and that emphasizing the role of climate change disguises the fomenting role of the Syrian regime (De Châtel 2014; Fröhlich 2016). This disunity in research conclusions extends to other geographic regions. Some argue that drought, combined with rising poverty and population, contributed to the crisis in Darfur (Sachs 2007). Others critique this emphasis on the role of climate change-induced or exacerbated drought, because it may be instrumentalized to obscure the underlying political dynamics and agency that drive such crises (Verhoeven 2011).

Findings derived from meta-analyses and synthetic research on the climate-conflict interface also diverge. A series of meta-analyses on quantitative studies found a direct causal association between climate change and increased conflict risk (Hsiang et al. 2013; Hsiang and Burke 2014; Burke et al. 2015). In response, Buhaug et al. (2014) developed an alternate meta-analysis and concluded that there is no conclusive direct climate-conflict relationship. Several other review articles are also skeptical about the direct climate-conflict link, citing weak evidence and insufficient empirical support (Bernauer et al. 2012; Sakaguchi et al. 2017); poor theoretical underpinnings (Meierding 2013) and lack of robust analysis (Peters et al. 2020); and different operationalizations and inadequate data on climate and conflict (Scheffran et al. 2012a; Salehyan 2014) that would lead to any decisive conclusions.

Much of the research that probes the relationships between disaster and conflict peppers their findings with qualifiers to try to avoid these controversies, but in doing so, inadvertently creates new gaps in understanding. Schleussner et al. (2016) claimed that disasters are statistically correlated with increased political instability and armed conflict in places that are "highly ethnically fractionalized." While ethnic diversity may be indirectly linked with conflict (Blimes 2006), cultural differences in a shared place may also create the opportunity for individuals and groups to build relationships and develop shared values (Wanis-St. John 2005). Collier and Hoeffler (2004) found that high ethnic diversity is a source for societal stability that leads to a lower risk of civil war than is the case in ethnically homogeneous states. Their work also established that societies with moderate ethnic heterogeneity and "ethnic dominance," where the largest ethnic group comprises $45 \%$ to $90 \%$ of the population, have double the risk of civil war onset. Ethnic divisions may not create conflict, but conflict may actually create, invent, or mobilize ethnic divisions (Collier 2000) and conceal heterogeneity within groups. These contrasting findings illustrate the need for a more nuanced consideration of the potential role of ethnicity (and perhaps other demographic and social identity factors) when examining the disaster-conflict link.

Consequently, no clear, uncontested linkages between disasters (incorporating hazard influencers such as climate change) and conflict have been established. Disaster may not lead immediately to conflict, but filter through escalating steps of risk, crisis, and conflict (Xu et al. 2016). The relationship between disasters and conflict may not follow a single and simple mechanism, but involve instead numerous mediating factors (Peters et al. 2019a). This wider array of causes and effects may make causal relationships more challenging and problematic to pinpoint, and several studies point out that much of the research focuses on direct relationships, while investigating indirect links may be necessary (Scheffran et al. 2012b; Theisen et al. 2013).

Other research has specifically investigated mediating factors, including the strength of institutions (Adano et al. 2012), economic factors (Hendrix and Glaser 2007; Bergholt and Lujala 2012; Koubi et al. 2012), and migration (Reuveny 2007). There may be a limited direct link between drought (and other hazards) and violence, but this relationship may be mitigated by local-level natural resource rules (Linke et al. 2018) or provision of key infrastructures (Detges 2016) to help people cope with environmental changes. The link between climate and conflict, for instance, may be more pronounced in agriculturally dependent or politically marginalized groups in very poor countries (von Uexkull et al. 2016). Additionally, disasters may have heterogeneous impacts on conflict (Nardulli et al. 2015) by exacerbating preexisting conflict (Brancati 2007; Omelicheva 2011; Pfaff 2020) and exacerbating and ameliorating certain conflict drivers and dynamics (Harris et al. 2013). These studies underline that any disaster-conflict relationship, especially with respect to climatic inputs, may be more of a reciprocal one than 
following a unidirectional causal chain (von Uexkull et al. 2016), and typically results from complex interactions in specific contexts (Olson and Gawronski 2017).

\section{Pivoting Toward Peace with Disaster Diplomacy}

Despite a significant focus on disaster-conflict relationships, other contributions expand their analytical gaze to examine the impacts of disasters on cooperation, collaboration, and peace. This research builds on the idea that there can be more cooperation than conflict over natural resources, and that resource scarcity has the potential to lead to enhanced cooperation or peace. For example, even in arid environments, interactions over international water resources are more likely to be cooperative (Wolf et al. 2003), and some posit that climate change-induced changes to water resources are unlikely to result in armed conflict (Bernauer and Siegfried 2012). Others go even further and claim that disasters may lead to a decrease in civil war risk (Slettebak 2012), provide opportunities to push along peace talks (Gaillard et al. 2008; Kreutz 2012), strengthen support for political leaders (Olson and Gawronski 2010), produce cooperation between conflicting parties (Endfield et al. 2004), and temporarily decrease crime rates and increase altruism (Lemieux 2014).

Inspired by such possibilities, disaster diplomacy scholarship crosses disciplinary boundaries to pursue the principal question of how and why disasters and disasterrelated activities do and do not reduce conflict and create greater cooperation or peace. This body of literature uses primarily qualitative methods to systematically gather evidence and conduct analyses on cases of disasters and disaster-related activities that yield compassionate or collaborative responses-including diplomacy-between parties at various scales (from international governance to household decision making), locations, distances from each other, and levels of formality (Kelman 2012). Disaster diplomacy differs from disaster-conflict research not only due to its focus on manifestations of peace, but also due to its expansion beyond a presumption of linear disasterconflict causality by exploring a range of human activities that deal with disasters that might influence conflict and peace processes and outcomes. However, disaster diplomacy has thus far been unable to establish causal linkages from disasters and disaster-related activities to diplomacy, peace, or cooperation. Ker-Lindsay $(2000,2007)$ suggested that disaster may have a "multiplying" effect on diplomacy when the foundations are already present. The word choice of this statement mirrors early climate-conflict literature, which suggests that climate change is a "threat multiplier" (CNA Corporation Military Advisory Board 2007), but avoids making the claim that disaster causes cooperation or peace.

Although the topic has long been discussed (Quarantelli and Dynes 1976; Comfort 1990), the subfield of disaster diplomacy coalesced more formally with Kelman and Koukis (2000) in a special issue of the Cambridge Review of International Affairs focused on formal and public interstate diplomatic interactions, considering disaster risk reduction (DRR) and disaster response/recovery. As the field grew, its analytical lens expanded to consider various - at times multiple and overlapping — spatial, temporal, and governance scales. Disaster diplomacy also began to consider vulnerability perspectives, localized initiatives, and multiple diplomacy tracks and players. Pre-disaster activities considered include warning systems and vaccinations, spatially diffuse hazard drivers such as creeping environmental changes, including climate change, and different diplomatic players at different scales, covering multi-track diplomacy (Diamond and McDonald 1993; Kurbalija and Katrandjiev 2006) alongside various forms of diplomacy including para-diplomacy, proto-diplomacy, and micro-diplomacy (Duchacek et al. 1988; Jackson 2018).

This move away from strictly interstate diplomacy by formal players opened up case studies of intrastate, subnational, supranational, and communal conflict and peace processes. Several studies (Scanlon 2006; Le Billon and Waizenegger 2007; Enia 2008; Gaillard et al. 2008; Klitzsch 2014) compared Aceh (Indonesia) and Sri Lanka following the 2004 Indian Ocean tsunami to disentangle how the tsunami and the responses to it may have contributed to peace in Aceh and renewed conflict in Sri Lanka. Ultimately, Gaillard et al. (2008) found that while the tsunami may have catalyzed diplomatic talks in Aceh, non-tsunami factors were more influential in short- and long-term peace negotiations. This conclusion reflects broader disaster diplomacy findings that where peaceful outcomes are observed, they are more often associated with political processes already oriented toward peace (Kelman 2012, 2016), incentive structures (Beardsley and McQuinn 2009), public support for a warming of relations (Akcinaroglu et al. 2011), and international interests and influence (Klitzsch 2014). And, frequently, disaster-related activities have no discernible impact on peace or conflict.

Disaster diplomacy studies have long acknowledged the multiscalar nature of conflicts. Conflicts may take place across governance scales, each interacting in different and intersecting ways with disasters and disaster-related activities. In a comparative case study of why interstate disaster diplomacy may have occurred in Greece-Turkey and not in India-Pakistan, Akcinaroglu et al. (2011) found that the presence of communal violence dampens the potential for rapprochement. Rajagopalan (2006) described that disaster 
diplomacy may be observed where humanitarian actions bring people together, encourage informal interactions, build mutual confidence, and provide opportunities to "rewrite the rules." The author acknowledged that conflict may also complicate disaster activities by directing relief or protection to certain groups or individuals. Peters et al. (2019b) suggested that cavalier DRR activities have the potential to escalate conflict in certain circumstances.

Ker-Lindsay (2007) noted that conflicts tend to be multidimensional, stemming from multiple factors, and they are dynamic as parties take various actions or inactions and as new issues emerge-a summary and ethos that matches the findings from decades of disaster research (Gaillard 2019). When viewed through a disaster diplomacy lens, "conflict and non-conflict disasters are inextricably linked" (Kelman 2012, p. 1), since both types of disasters are constructed through patterns of human action and inaction and emerge from this history. Acknowledging the multidimensionality and complexity of disasters, conflict, and peace - and their relationships - helps to explain why disaster diplomacy makes such modest claims about influencing disaster and diplomacy trajectories.

According to disaster diplomacy scholarship, even for short-term effects to manifest, the foundations for conflict or peace must already be present. Peace begets peace and conflict begets conflict, with disasters and disaster-related activities (including dealing with hazard influencers such as climate change) sometimes being used as an opportunity to pursue pre-established peace or conflict pathways. Corroborating other areas of investigation, neither disasterrelated activities nor conflict-related activities are divorced from the social, political, and economic systems in which they operate. Rather, they perpetuate and reflect the societal conditions in which they occur. Disaster, conflict, and their related activities such as DRR (including climate change adaptation) and peacebuilding are long-term and diffuse processes that complicate the search for linear and causal relationships between disaster and conflict or between disaster and peace. These challenges can and should be overcome to yield insights into how to better reduce different forms of disaster and violence in tandem, by learning from and connecting work across this spectrum of topics.

Scholars continue to strive toward understanding why and how disaster may catalyze peaceful outcomes in certain circumstances, and renewed or exacerbated conflict in others. Greater consideration of the nuances of conflict and peace dynamics may be essential for understanding the disaster-conflict-peace nexus, not only in terms of "how" and "why," but also in terms of "when," "where," and "who" - and how to use the answers to improve actions in favor of reducing disaster risk and supporting peace.

\section{Fundamentals Linking Disaster, Conflict, and Peace Research}

Overall, decisive conclusions on the disaster-conflict-peace nexus have evaded scientific consensus in part due to conceptual, methodological, and interpretive differences among studies. This should not be the case, given how many of the starting points and challenges yet to overcome are similar between fields.

\subsection{Intersecting (Mis)understandings}

How disaster, peace, and conflict are defined, parameterized, and measured often differs among studies, and this yields disparate findings. Databases for disaster and conflict paint these phenomena as event-based, binary (existing or not), and comparable via death or damage figures. Various authors have challenged the uncritical usage of the EM-DAT database for disasters (Moriyama et al. 2018), with the DesInventar database increasingly being adopted for quantitative studies (Gaillard et al. 2019). Commonly used conflict databases_-such as the Armed Conflict Location and Event Data Project (ACLED), and the Uppsala Conflict Data Program in conjunction with the Peace Research Institute Oslo (UCDP/PRIO) - display similar biases (Eck 2012). One way forward could be to fully accept conflicts as disasters in order to pool knowledge about the difficulties in setting up and maintaining such databases and then work across fields to overcome the difficulties.

The same could be true for theoretical and conceptual underpinnings of disaster, conflict, and peace. In disaster literature, conflict can be (mis)understood as purely destructive, while conflict and peace literature can presume the same for disaster. Peace, if it is considered at all, can be conceptualized as the absence of violence rather than as the presence of various phenomena. Peace can be assumed as the condition when a war is not active, under a categorical threshold, or as following a peace agreement, ceasefire, or other political arrangement. Similarly, after the so-called recovery phase, a disaster can be accepted as having been overcome when people are returning "back to normal." Rather than siloed literature adopting debunked approaches from the other areas, working together would reveal how key fundamental points are the same, such as that disaster, conflict, and peace are all dynamic, nonlinear, and potentially co-occurring processes, driven primarily by social decisions from those with the most power and resources.

Some conflict and peace scholarship still employs the misnomer "natural disaster" and adopts hazards or hazard influencers (for example, climate change) as causes of disasters, thereby bypassing the foundations of disaster 
research that disasters are not natural because they are caused by vulnerabilities (Hewitt 1983; Lewis 1999; Wisner et al. 2004). Yet, while disasters are neither natural nor inevitable, social conflicts are an inherent and inevitable part of human interactions (Lederach 1997; Kriesberg 2007) that surface "when two or more persons or groups manifest the belief that they have incompatible objectives" (Kriesberg 2007, p. 2). In effect, conflict refers to perceived or real differences in how individuals or collectives think or act, and, since heterogeneity always exists, conflict exists in all societies. The destructiveness and trajectories of conflicts, however, are not inevitable and they vary (Lederach 1997; Kriesberg 2007), with conflicts at any stage of escalation or de-escalation potentially being pursued nonviolently and constructively, and/or violently or destructively (Kriesberg 2007). Constructive conflict may produce widespread benefits (Deutsch 1994; Kriesberg 2007), while destructive conflict often produces further grievances or hatred (Collier 2000; Ballentine and Sherman 2003).

The constructiveness or destructiveness of conflict in large part hinges on engagement - by choice or by habitwith social practices of violence. An expanded understanding of violence takes it to be forms of direct, structural, and cultural violence-which is sometimes applied to the definition of disaster as well (Deloughrey et al. 2015). Direct violence refers to physical violence (for example, assault); structural violence refers to indirect institutional forms of violence (for example, poverty, discrimination, and hunger); and cultural violence refers to the cultural beliefs that normalize direct and structural forms of violence (for example, the religious beliefs that underpin a caste system and laws that promote racism) (Galtung 1969, 1990). Cultural violence persuades those within a society to see certain forms of exploitation and repression as natural and normal, or not to see them at all. These interpretations of violence intersect with disaster studies, which sometimes interpret the imposition and perpetuation of vulnerabilities that cause disasters as structural and cultural-and sometimes direct-violence. Examples of authors who provide theoretical constructions that make this bridge include:

- Hartmann and Boyce (1983) describing "quiet violence" as exploitation, poverty, and hunger.

- Watts (1983) conceptualizing "silent violence" as the social causes of famines, irrespective of environmental inputs into droughts.

- Nixon (2011) detailing "slow violence" as the adverse consequences on people of environmental destruction, including pollution.

Misunderstanding peace can also cause difficulties for disaster-related activities. In conflict and peace literature, negative peace is discussed as the mere absence of direct violence, and positive peace as "the absence/reduction of violence of all kinds" and "nonviolent and creative conflict transformation" (Galtung 1996, p. 9). Achieving negative peace without building elements of positive peace typically reverts to direct displays of violence, as the underlying causes of violent conflict are left unaddressed. However, what constitutes positive peace is highly value laden, sprawling, and controversial, not to mention difficult to quantify and compare across time and place. In practice, Autesserre (2014) juxtaposed how those working in peace operations and humanitarian and development interventions may define "peace" as a reduction in violence, while local community members may understand "peace" as the ability to send their children to school. Knowing conflict and peace may shift from place to place and person to person, and potential disagreement over what constitutes conflict and/or peace may itself be a source of conflict. As with "disaster," these concepts are socially produced and reproduced, hence they also change over time, influencing and being influenced by contemporary social norms.

\subsection{Politics and Power}

It follows that DRR and peacebuilding concepts and activities are not socially or politically neutral, as change is initiated, decided upon, and implemented by a group or groups with a political agenda-matching the ethos of disaster research and the cultures and power relations driving the work (Krüger et al. 2015). Both DRR and peacebuilding may be instrumentalized to protect the status quo (from international to local and individual scales) and established forms of governance (including the legitimization of sovereign nation states and the political parties or individuals running them). Peace itself and efforts to maintain or build it may be founded on the premise of violence expressed through multiple forms (Mitchell 2011), as occurs for DRR when claims of tsunami or storm surge safety are used as the reasons for transferring coastal land from poor people to rich people (Cohen 2011; Baptiste and Devonish 2019). Various actors may pursue conflicts through constructive and/or destructive strategies to improve their situations and lives, while others may be threatened or materially hurt by these DRR (Gaillard 2012) and peace-seeking actions (Kriesberg 2007). Conflict (as with disaster-related activities; see Sect. 3) may serve as an essential catalyst for change (Miall 2004), though the direction and perception of this change may be hotly contested between and within groups.

Disaster politics-like peace and conflict politics-are complex and involve a multiplicity of actors at various scales. These actors often have a history of pre-disaster interactions, with patterns tending toward conflict or peace. 
Formal actors may create or perpetuate disaster vulnerabilities through actions that they knowingly choose to serve the interests of those in power, accept due to lack of capacity or externally imposed limitations, or pursue due to short-term interests (Hewitt 1983; Lewis 1999; Wisner et al. 2004). Disaster can spur governmental and societal actions and inactions with new demands and opportunities, and, critically, these actions interact with each other as well as with previous political conditions and divisions (Gawronski and Olson 2013). Disasters can expose local violence that typifies long-term conditions, but is newly made known to the international community (Marcelin 2015). Disasters can also provide opportunities for international actors to intervene and proliferate in local contexts, with the potential to shift power dynamics (Marcelin 2011) or advance neoliberal interests (Klein 2007).

Conflict transformation acknowledges that internal social processes are in a continual and nonlinear process of change (Lederach 1995; Reimann 2004) toward a vision or visions of the future (Lederach 1995), even without interventions. Following in the traditions of Galtung, Curle, and Lederach, long-term and deliberate conflict transformation and peacebuilding processes arise to overcome direct, cultural, and structural violence (Reimann 2004) by transforming actors, issues, structures, and rules (Väyrynen 1991) that contribute to an ongoing conflict situation and promote constructive conflict (Deutsch 1994) and positive peace. Peacemakers work with parties in conflict to develop power-balanced relationships, awareness of their conflict, and awareness of their agency in changing their conflict (Curle 1971). In order for meaningful transformation to occur, it must be paired with voluntary and deep commitment to comply with decisions that are made (Deetz 2017), and it must also be paired with reconciliation between conflicting groups (Lederach 1997). Disaster risk reduction that incorporates these principles and practices might have the potential to transform conflict and build peace as part of reducing disaster vulnerabilities, but there is thus far limited evidence of success.

Despite these admirable goals, the field of peacebuilding has had an unimpressive track record at de-escalating destructive conflict and achieving and sustaining peace and equitable relationships between former adversaries. Even metrics for determining success are disputed (Call 2008). It is the same for disaster-related activities, which cannot be systematically shown to influence conflict and peace in the long term (Kelman 2012, 2016). Disaster has a relationship with conflict enacted through vulnerabilities, but that does not necessarily mean that DRR contributes to conflict prevention or peacebuilding (Peters et al. 2019b). Yet, the metrics for disaster diplomacy success might be too stringently defined; they poorly factor in conflict and peace literature; and they require much more work to incorporate the complexities and uncertainties identified regarding disaster, conflict, and peace interactions across time, space, and governance scales, with the necessarily broad range of actors. Furthermore, the framing to date of the core question of disaster diplomacy-how and why disaster-related activities before, during, and after disasters do and do not affect different forms of conflict and peace-may be incomplete by not explicitly asking about when, where, and who.

\subsection{Joining the Pieces}

One pattern that is emerging is support for the foundational literature from disaster research (Hewitt 1983; Lewis 1999; Wisner et al. 2004), and from peace and conflict studies research (Galtung 1969; Lederach 1995), that disaster, conflict, and peace are inherently political, arising from long-term processes deeply ingrained in society, rather than resulting from simple relationships and definitive starting, ending, or tipping points. The confusion among the different fields and disagreements alongside sometimes contradictory findings indicate that these topics are approached from siloed perspectives that do not always intersect with or learn from each other. Similar baselines, ethoses, and challenges mean their interconnections could be much better demonstrated and common problems more comprehensively addressed.

Disaster and conflict risks may stem from the same underlying vulnerabilities within a given society, and they both may catalyze societal change. Figure 1 illustrates how co-occurring "conflict" and "peace" processes are nested within different expressions and strategies. Violent expressions stemming from conflict and peace processes may reinforce each other and move toward similar outcomes; for disaster studies, these outcomes may be linked to increased disaster vulnerabilities. Likewise, cooperative expressions stemming from conflict and peace processes may reinforce each other and move toward similar outcomes; for disaster studies, these outcomes may be linked to increased disaster coping capacities. While research may focus on conflict and peace, these should be seen as entry points to a wider array of potential questions using a peace and conflict lens.

Figure 1 provides a conceptual approach that can serve to disaggregate as well as connect findings. For example, the debates surrounding the extent to which disaster and climate change contribute to conflict (or not) would be enriched by characterizing pre-disaster conflict and peace processes, linking these with disaster vulnerabilities and coping capacities, and tracing how disaster and the human actions that surround it reflect or depart from these patterns (see also the critical juncture analysis conducted by Gawronski and Olson 2013). These robustly drawn 
Fig. 1 A conceptual model of how nested expressions of peace and conflict affect disaster risk, leading to joint disaster-conflictpeace research

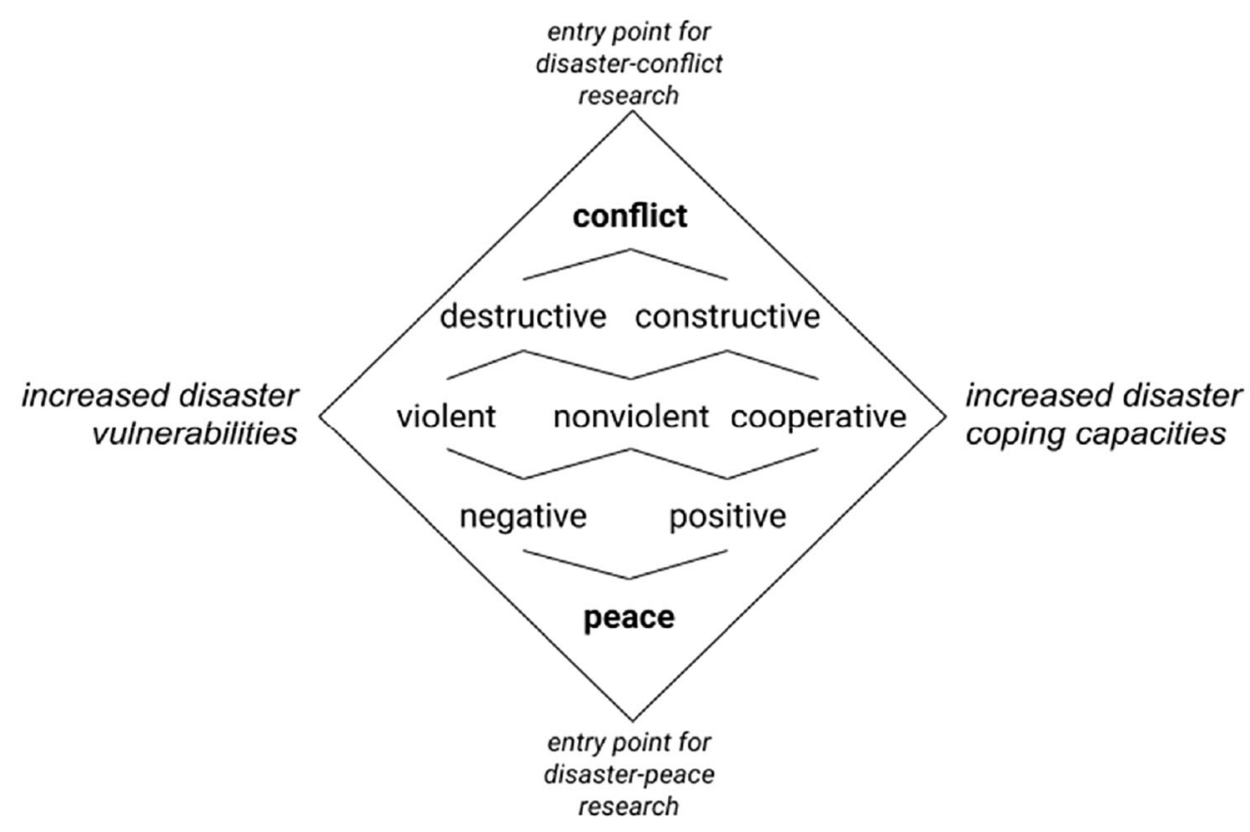

conclusions will help to explain how disaster vulnerabilities and violence may become linked in a self-perpetuating process and, conversely, how disaster coping capacities and cooperation may reinforce a chain of positive feedbacks. Peace and conflict may be the visible tips of much deeper processes of social and political change.

When exploring the linkages between disaster and conflict, scholars should dig deeper to engage with the nuances of constructive and destructive conflict strategies and how they manifest through direct, structural, and cultural forms of violence. When exploring the linkages between disaster and peace, scholars should investigate beyond the concept of negative peace and additionally assess whether there are elements of positive peace or if the prevailing "peace" actually entrenches direct, structural, and cultural forms of violence. Where disaster is considered as a conflict or peace multiplier, it should be situated within peace and conflict processes that are already under way. This is in line with disaster diplomacy findings that non-disaster factors are more influential in conflict and peace. But, we can and must dig deeper into understanding more precisely where, when, and how disasters and disaster-related activities impact these processes, even in the short term. Conversely, taking a longer-term view could provide additional insights into how post-disaster, shortterm violence or cooperation might lead to later reconfigurations balancing conflict and peace.

Conflict and peace processes engage in broader longterm, multipronged, and nonlinear change processes across intersecting scales. Scholarship on the disaster-conflictpeace nexus should move beyond seeing disaster and conflict as event-based and isolatable, to pursue instead ways of studying them as intrinsically linked in long-term, co-occurring processes and complex systems of risk. Where these processes lean toward cooperative manifestations, they may reduce or transform disaster-conflict risks through coping capacities. Where these processes are more violent, they may enhance or entrench disaster-conflict risks through vulnerabilities.

These connections require far more prominence in policy as well. The globally agreed frameworks for DRR, the Hyogo Framework for Action 2005-2015 and the Sendai Framework for Disaster Risk Reduction 2015-2030 (UNISDR 2005, 2015), do not engage with conflict, violence, or war, nor do they provide guidance for how to adapt programming to conflict-affected contexts, despite the fact that conflict-affected and fragile countries are among the signatories of these agreements (Peters et al. 2019c). The Hyogo Framework briefly advocates for an integrated, multi-hazard approach to DRR in disaster-prone settings, including "postconflict" contexts, but there is no further discussion of strategic recommendations in such contexts. The more recent Sendai Framework includes no mention of conflict, peace, and related key terms and concepts (Peters et al. 2019c). Siloed approaches to complex problems (including disaster and conflict) have even been criticized by the UN itself: UN Secretary-General António Guterres warned, "[...] we are in a world in which global challenges are more integrated, and the responses are more and more fragmented. And, if these are not reversed, it is a recipe for disaster" (World Economic Forum 2019, para. 1).

The UN could start by drawing from its own knowledge base in developing nexus approaches to address disaster 
and conflict. A United Nations Development Programme (2011) report found that disasters can contribute to conflicts, and that disasters and conflicts together can increase the risk of crises. This same study found that DRR has been used in post-conflict situations as a tool to build peace, and these efforts may have yielded unique benefits due to being less contentious than direct forms of conflict resolution (UNDP 2011). For disaster-related activities, turning away from conflict does not mean that these activities can avoid conflict or become somehow conflict-neutral. Instead, opportunities to reduce disaster and conflict risk effectively and simultaneously will be missed, with a possibility for potentially causing harm, as sometimes occurs with wellintentioned humanitarian interventions for disasters and conflict (Anderson 1999).

\section{Conclusion and Future Directions}

This article has provided a critiquing overview of the intersections of disaster, conflict, and peace research, highlighting disaster diplomacy as one example that shows how much more work is needed. Wider formulations of disaster-politics interactions (Glantz 1976) have not been considered in the analysis here, including the conflicts inherent in disaster declarations (Platt 1999), the contemporary information democracy that influences disaster-related activities (Alexander 2014), or the ethical discussions regarding whether or not many disaster, conflict, and peace activities can be entirely apolitical through neutrality and impartiality (Seybolt 1996). The overall findings here nonetheless demonstrate parallels between some fundamentals of disaster research and those of conflict and peace research, as well as a lack of evidence that disaster-related activities create new directions for conflict and peace endeavors.

Disaster-related activities are shown to influence, rather than create, peace and conflict in a variety of ways, illustrating the multitude of causal pathways at play. The deliberate and habitual actions and inactions taken by different actors at various temporal, spatial, and governance scales interact and produce different outcomes at different levels of influence and at different scales. As such, disparate literatures converge to suggest that disaster, conflict, and peace are embedded within long-term societal processes that are socially constructed, nonlinear, and dynamic. This scholarship supports the need to reframe research, policy, and practice away from deterministic or fatalistic understandings and toward the active pursuit of specific pathways that reduce or transform disaster and conflict risk and contribute to flourishing societies that are well-poised to tackle current and future challenges. These directions further demonstrate the crucial role of those with power and resources in making decisions at multiple levels of governance in favor of tackling disasters and promoting peace simultaneously. Yet, these decisions often reflect a preference for violence and a lack of disaster-related activities. Consequently, consistent linear and causal relationships between disasters and conflict/peace are likely to remain elusive and inconclusive, as disaster diplomacy, for instance, has thus far suggested.

The evidence does not negate the possibility that disaster-related activities present iterative opportunities to create or seed a fledgling conflict or peace process-perhaps at specific spatial, temporal, and governance scaleswhich then takes hold and proceeds. Counterexamples might yet emerge from historical case studies or where future disaster-related activities could be shown to create new and lasting conflict or peace.

The intersections of disaster, conflict, and peace research, and the gaps in them, also reveal directions for further work. This research points to the need to develop a theoretical framework to bring together disaster, conflict, and peace research and to foster joint work between academic, intergovernmental, nongovernmental, governmental, and private sector institutions in long-term collaborations. Bringing together disaster, conflict, and peace scholars and practitioners has also been suggested by others, not only to jointly generate knowledge and build skills on the positive relationships but also to identify where there are insignificant relationships (Gawronski and Olson 2013) and limitations to nexus programming (Peters 2019). The goal of these integrated approaches in applied settings would be to simultaneously support peace, reduce conflict, and tackle disaster risks.

Could there be opportunities for disaster-related activities to perhaps not create peace and reduce conflict, but to support experiments and testbeds at various scales? How could the silos of disaster, conflict, and peace research deepen each one's engagement with (1) foundational research and the rich history of the others, and (2) the latest developments in the other fields, ranging from conflict transformation to complex systems of risk? Specific ways of answering these questions include:

(1) Academia providing conference, journal, and book opportunities in which researchers who focus on specific areas of disaster, conflict, and peace are brought together to collaborate.

(2) Generating training and education opportunities that start from the common bases of disaster, conflict, and peace research in order to generate skills and advice that cover all areas.

(3) Offering joint work and expertise to support programs and projects from intergovernmental, nongovernmental, private sector, and governmental institutions in 
simultaneously supporting peace, reducing conflict, and tackling disaster risk.

Practitioners and policymakers across sectors have opportunities to shape disaster, conflict, and peace activities, policies, and frameworks, but the results do not always end up as intended. Continuing research and applications that actively seek to fill these gaps in understanding will assist in informing them when, where, and how to act.

Open Access This article is licensed under a Creative Commons Attribution 4.0 International License, which permits use, sharing, adaptation, distribution and reproduction in any medium or format, as long as you give appropriate credit to the original author(s) and the source, provide a link to the Creative Commons licence, and indicate if changes were made. The images or other third party material in this article are included in the article's Creative Commons licence, unless indicated otherwise in a credit line to the material. If material is not included in the article's Creative Commons licence and your intended use is not permitted by statutory regulation or exceeds the permitted use, you will need to obtain permission directly from the copyright holder. To view a copy of this licence, visit http://creativecommons. org/licenses/by/4.0/.

\section{References}

Acuto, M. (ed.). 2014. Negotiating relief: The dialectics of humanitarian space. London: Hurst Publishers.

Adano, W.R., T. Dietz, K. Witsenburg, and F. Zaal. 2012. Climate change, violent conflict and local institutions in Kenya's drylands. Journal of Peace Research 49(1): 65-80.

Akcinaroglu, S., J.M. Dicicco, and E. Radziszewski. 2011. Avalanches and olive branches: A multimethod analysis of disasters and peacemaking in interstate rivalries. Political Research Quarterly 64(2): 260-275.

Alexander, D.E. 2014. Social media in disaster risk reduction and crisis management. Science and Engineering Ethics 20(3): 717-733.

Alexander, D. 2020. How to manage an emergency or disaster. Edinburgh: Dunedin Academic Press.

Anderson, M.B. 1999. Do no harm: How aid can support peace-or war. Boulder, CO: Lynne Rienner Publishers.

Autesserre, S. 2014. Peaceland: Conflict resolution and the everyday politics of international intervention. New York: Cambridge University Press.

Baldwin, A., C. Fröhlich, and D. Rothe. 2019. From climate migration to Anthropocene mobilities: Shifting the debate. Mobilities 14(3): 289-297.

Ballentine, K., and J. Sherman. 2003. Introduction. In The political economy of armed conflict: Beyond greed and grievance, ed. $\mathrm{K}$. Ballentine, and J. Sherman, 1-15. Boulder, CO and London: Lynne Rienner Publishers.

Baptiste, A.K., and H. Devonish. 2019. The manifestation of climate injustices: The post-Hurricane Irma conflicts surrounding Barbuda's communal land tenure. Journal of Extreme Events 6(1): Article 1940002

Beardsley, K., and B. McQuinn. 2009. Rebel groups as predatory organizations: The political effects of the 2004 tsunami in Indonesia and Sri Lanka. The Journal of Conflict Resolution 53(4): 624-645.
Bergholt, D., and P. Lujala. 2012. Climate-related natural disasters, economic growth, and armed civil conflict. Journal of Peace Research 49(1): 147-162.

Bernauer, T., and T. Siegfried. 2012. Climate change and international water conflict in Central Asia. Journal of Peace Research 49(1): 227-239.

Bernauer, T., T. Böhmelt, and V. Koubi. 2012. Environmental changes and violent conflict. Environmental Research Letters 7(1): Article 015601.

Berrebi, C., and J. Ostwald. 2011. Earthquakes, hurricanes, and terrorism: Do natural disasters incite terror? Public Choice 149(3): 383-403.

Bhavnani, R. 2006. Natural disaster conflicts. Cambridge, MA: Harvard University.

Blimes, R.J. 2006. The indirect effect of ethnic heterogeneity on the likelihood of civil war onset. Journal of Conflict Resolution 50(4): 536-547.

Brancati, D. 2007. Political aftershocks: The impact of earthquakes on intrastate conflict. Journal of Conflict Resolution 51(5): $715-743$.

Brzoska, M. 2018. Weather extremes, disasters, and collective violence: Conditions, mechanisms, and disaster-related policies in recent research. Current Climate Change Reports 4(4): $320-329$

Buhaug, H. 2010. Climate not to blame for African civil wars. Proceedings of the National Academy of Sciences 107(38): 16477-16482.

Buhaug, H., J. Nordkvelle, T. Bernauer, T. Böhmelt, M. Brzoska, J.W. Busby, A. Ciccone, H. Fjelde, et al. 2014. One effect to rule them all? A comment on climate and conflict. Climatic Change 127(3): 391-397.

Burke, M., S.M. Hsiang, and E. Miguel. 2015. Climate and conflict. Annual Review of Economics 7: 577-617.

Call, C.T. 2008. Knowing peace when you see it: Setting standards for peacebuilding success. Civil Wars 10(2): 173-194.

Carlin, R.E., G.J. Love, and E.J. Zechmeister. 2014. Natural disaster and democratic legitimacy: The public opinion consequences of Chile's 2010 earthquake and tsunami. Political Research Quarterly 67(1): 3-15.

Carroll, M.S., L.L. Higgins, P.J. Cohn, and J. Burchfield. 2006. Community wildfire events as a source of social conflict. Rural Sociology 71(2): 261-280.

CNA Corporation Military Advisory Board. 2007. National security and the threat of climate change. Alexandria: The CNA Corporation.

Cohen, E. 2011. Tourism and land grab in the aftermath of the Indian Ocean Tsunami. Scandinavian Journal of Hospitality and Tourism 11(3): 224-236.

Collier, P. 2000. Economic causes of conflict and their implications for policy. Economics of Crime and Violence Paper. Washington, DC: World Bank.

Collier, P., and A. Hoeffler. 2004. Greed and grievance in civil war. Oxford Economic Papers 56(4): 563-95.

Comfort, L.K. 1990. Turning conflict into cooperation: Organizational designs for community response in disasters. International Journal of Mental Health 19(1): 89-108.

Curle, A. 1971. Making peace. London: Tavistock Publications.

Dany, C. 2018. Failed cooperation in times of natural disasters: Explaining the rejection of humanitarian aid. International Relations of the Asia-Pacific 20(2): 193-223.

De Châtel, F. 2014. The role of drought and climate change in the Syrian uprising: Untangling the triggers of the revolution. Middle Eastern Studies 50(4): 521-535.

Deetz, S. 2017. Disarticulation and conflict transformation: Interactive design, collaborative processes, and generative democracy. In Communication and conflict transformation through local, 
regional, and global engagement, ed. P.M. Kellett, and T.G. Matyók. Lanham, MD: Lexington Books.

Deloughrey, E., J. Didur, and A. Carrigan (eds.). 2015. Global ecologies and the environmental humanities: Postcolonial approaches. Abingdon, UK: Routledge.

Detges, A. 2016. Local conditions of drought-related violence in subSaharan Africa: The role of road and water infrastructures. Journal of Peace Research 53(5): 696-710.

Deutsch, M. 1994. Constructive conflict resolution: Principles, training, and research. Journal of Social Issues 50(1): 13-32.

Diamond, L., and J. McDonald. 1993. Multi-track diplomacy: A systems approach to peace. Washington, DC: Institute for MultiTrack Diplomacy.

Duchacek, I., D. Latouche, and G. Stevenson (eds.). 1988. Perforated sovereignties and international relations: Trans-sovereign contacts of sub-national governments. Westport, CT: Greenwood Press.

Dynes, R.R., and E.L. Quarantelli. 1968. What looting in civil disturbances really means. Trans-Action 5(6): 9-14.

Eck, K. 2012. In data we trust? A comparison of UCDP GED and ACLED conflict events datasets. Cooperation and Conflict 47(1): 124-141.

Endfield, G.H., I.F. Tejado, and S.L. O'Hara. 2004. Conflict and cooperation: Water, floods, and social response in colonial Guanajuato, Mexico. Environmental History 9(2): 221-247.

Enia, J. 2008. Peace in its wake? The 2004 tsunami and internal conflict in Indonesia and Sri Lanka. Journal of Public and International Affairs 19: 7-27.

Fisher, S. 2010. Violence against women and natural disasters: Findings from post-tsunami Sri Lanka. Violence Against Women 16(8): 902-918.

Flores, A.Q., and A. Smith. 2013. Leader survival and natural disasters. British Journal of Political Science 43(4): 821-843.

Fröhlich, C. 2016. Climate migrants as protestors? Dispelling misconceptions about global environmental change in prerevolutionary Syria. Contemporary Levant 1(1): 38-50.

Gaillard, J.C. 2012. The climate gap. Climate and Development 4(4): 261-264.

Gaillard, J.C. 2019. Disaster studies inside out. Disasters 43(S1): S7S17.

Gaillard, J.C., E. Clave, and I. Kelman. 2008. Wave of peace? Tsunami disaster diplomacy in Aceh, Indonesia. Geoforum 39: $511-526$

Gaillard, J.C., D. van Niekerk, L.B. Shorom, C. Coetzee, and T. Amirapu. 2019. Wildlife hazards and disaster risk reduction. International Journal of Disaster Risk Reduction 33: 55-63.

Galtung, J. 1969. Violence, peace, and peace research. Journal of Peace Research 6(3): 167-191.

Galtung, J. 1990. Cultural violence. Journal of Peace Research 27(3): 291-305.

Galtung, J. 1996. Peace by peaceful means: Peace and conflict, development and civilization. Oslo: International Peace Research Institute.

Gawande, K., D. Kapur, and S. Satyanath. 2017. Renewable natural resource shocks and conflict intensity: Findings from India's ongoing Maoist insurgency. Journal of Conflict Resolution 61(1): 140-172.

Gawronski, V.T., and R.S. Olson. 2013. Disasters as crisis triggers for critical junctures? The 1976 Guatemala case. Latin American Politics and Society 55(2): 133-149.

Glantz, M.H. 1976. The politics of natural disaster: The case of the Sahel drought. New York: Praeger.

Harris, K., D. Keen, and T. Mitchell. 2013. When disasters and conflicts collide: Improving links between disaster resilience and conflict. London: Overseas Development Institute.
Hartmann, B. 2010. Rethinking climate refugees and climate conflict: Rhetoric, reality and the politics of policy discourse. Journal of International Development 22(2): 233-246.

Hartmann, B., and J.K. Boyce. 1983. A quiet violence: View from a Bangladesh village. London: Zed Books.

Hendrix, C.S., and S.M. Glaser. 2007. Trends and triggers: Climate, climate change and civil conflict in sub-Saharan Africa. Political Geography 26(6): 695-715.

Hendrix, C.S., and I. Salehyan. 2012. Climate change, rainfall, and social conflict in Africa. Journal of Peace Research 49(1): $35-50$.

Hewitt, K. (ed.). 1983. Interpretations of calamity from the viewpoint of human ecology. London: Allen \& Unwin.

Homer-Dixon, T.F. 1994. Environmental scarcities and violent conflict: Evidence from cases. International Security 19(1): $5-40$.

Homer-Dixon, T.F. 1999. Environment, scarcity, and violence. Princeton: Princeton University Press.

Hsiang, S.M., and M. Burke. 2014. Climate, conflict, and social stability: What does the evidence say? Climatic Change 123(1): $39-55$.

Hsiang, S.M., M. Burke, and E. Miguel. 2013. Quantifying the influence of climate on human conflict. Science 341(6151): Article 1235367.

Jackson, T. 2018. Paradiplomacy and political geography: The geopolitics of substate regional diplomacy. Geography Compass 12(2): Article e12357.

Kahl, C.H. 2006. States, scarcity, and civil strife in the developing world. Princeton: Princeton University Press.

Kelley, C.P., S. Mohtadi, M.A. Cane, R. Seager, and Y. Kushnir. 2015. Climate change in the Fertile Crescent and implications of the recent Syrian drought. Proceedings of the National Academy of Sciences 112(11): 3241-3246.

Kelman, I. 2012. Disaster diplomacy: How disasters affect peace and conflict. Abingdon, UK: Routledge.

Kelman, I. 2016. Catastrophe and conflict: Disaster diplomacy and its foreign policy implications. Brill Research Perspectives in Diplomacy and Foreign Policy 1(1): 1-76.

Kelman, I., and T. Koukis (eds.). 2000. Disaster Diplomacy, special section in Cambridge Review of International Affairs 14(1): 214-294.

Ker-Lindsay, J. 2000. Greek-Turkish rapprochement: The impact of 'disaster diplomacy'? Cambridge Review of International Affairs 14(1): 215-232.

Ker-Lindsay, J. 2007. Crisis and conciliation: A year of rapprochement between Greece and Turkey. London: I.B.Tauris.

Klein, N. 2007. The shock doctrine: The rise of disaster capitalism. New York: Metropolitan Books.

Klitzsch, N. 2014. Disaster politics or disaster of politics? Posttsunami conflict transformation in Sri Lanka and Aceh, Indonesia. Cooperation and Conflict 49(4): 554-573.

Koubi, V., T. Bernauer, A. Kalbhenn, and G. Spilker. 2012. Climate variability, economic growth, and civil conflict. Journal of Peace Research 49(1): 113-127.

Kreutz, J. 2012. From tremors to talks: Do natural disasters produce ripe moments for resolving separatist conflicts. International Interactions: Empirical and Theoretical Research in International Relations 38(4): 482-502.

Kriesberg, L. 2007. Constructive conflicts: From escalation to resolution, 3rd edn. Lanham, MD: Rowman \& Littlefield.

Krüger, F., G. Bankoff, T. Cannon, B. Orlowski, and E.L. Schipper (eds.). 2015. Cultures and disasters: Understanding cultural framings in disaster risk reduction. Abingdon, UK: Routledge.

Kurbalija, J., and V. Katrandjiev (eds.). 2006. Multistakeholder diplomacy: Challenges and opportunities. Msida, Malta: DiploFoundation. 
Le Billon, P., and A. Waizenegger. 2007. Peace in the wake of disaster? Secessionist conflicts and the 2004 Indian Ocean Tsunami. Transactions of the Institute of British Geographers 32(3): 411-427.

Lederach, J.P. 1995. Preparing for peace: Conflict transformation across cultures. Syracuse, NY: Syracuse University Press.

Lederach, J.P. 1997. Building peace: Sustainable reconciliation in divided societies. Washington, DC: United States Institute of Peace.

Lemieux, F. 2014. The impact of a natural disaster on altruistic behaviour and crime. Disasters 38(3): 483-499.

Lewis, J. 1999. Development in disaster-prone places: Studies of vulnerability. London: Intermediate Technology Publications.

Linke, A.M., F.D.W. Witmer, J. O'Loughlin, J.T. McCabe, and J. Tir. 2018. Drought, local institutional contexts, and support for violence in Kenya. Journal of Conflict Resolution 62(7): 1544-1578.

Marcelin, L.H. 2011. Cooperation, peace and (re-)construction? A tale from the shanties. Journal of Peacebuilding \& Development 6(3): 53-69.

Marcelin, L.H. 2015. Violence, human insecurity, and the challenge of rebuilding Haiti: A study of a shantytown in Port-au-Prince. Current Anthropology 56(2): 230-255.

Meierding, E. 2013. Climate change and conflict: Avoiding small talk about the weather. International Studies Review 15(2): 185-203.

Miall, H. 2004. Conflict transformation: A multi-dimensional task. In Transforming ethnopolitical conflict: The Berghof handbook, ed. A. Austin, M. Fischer, and N. Ropers, 67-89. Wiesbaden: Springer-Verlag.

Mitchell, A. 2011. Lost in transformation: Violent peace and peaceful conflict in Northern Ireland. London: Palgrave Macmillan.

Moriyama, K., D. Sasaki, and Y. Ono. 2018. Comparison of global databases for disaster loss and damage data. Journal of Disaster Research 13(6): 1007-1014.

Nardulli, P.F., B. Peyton, and J. Bajjalieh. 2015. Climate change and civil unrest: The impact of rapid-onset disasters. Journal of Conflict Resolution 59(2): 310-335.

Nel, P., and M. Righarts. 2008. Natural disasters and the risk of violent civil conflict. International Studies Quarterly 52(1): $159-185$.

Nelson, T. 2010. When disaster strikes: On the relationship between natural disaster and interstate conflict. Global Change, Peace \& Security 22(2): 155-174.

Nicholson, C.T.M. 2014. Climate change and the politics of causal reasoning: The case of climate change and migration. The Geographical Journal 180(2): 151-160.

Nixon, R. 2011. Slow violence and the environmentalism of the poor. Cambridge, MA: Harvard University Press.

Nogami, T. 2018. Disaster myths among disaster response professionals and the source of such misconceptions. Journal of Contingencies and Crisis Management 26(4): 491-498.

Olson, R.S., and V.T. Gawronski. 2010. From disaster event to political crisis: A " $5 \mathrm{C}+\mathrm{A}$ " framework for analysis. International Studies Perspectives 11(3): 205-221.

Olson, R.S., and V.T. Gawronski. 2017. Violent conflict and disaster risk reduction including climate change adaptation. In The Routledge handbook of disaster risk reduction including climate change adaptation, ed. I. Kelman, J. Mercer, and J.C. Gaillard, 150-160. London and New York: Routledge.

Omelicheva, M.Y. 2011. Natural disasters: Triggers of political instability? International Interactions 37(4): 441-465.

Pfaff, K. 2020. Assessing the risk of pre-existing grievances in nondemocracies: The conditional effect of natural disasters on repression. International Journal of Disaster Risk Reduction 42: 101337. https://doi.org/10.1016/j.ijdrr.2019.101337.
Peters, K. 2019. Disaster risk reduction in conflict contexts: An agenda for action. London: Overseas Development Institute.

Peters, K., K. Holloway, and L.E.R. Peters. 2019a. Disaster risk reduction in conflict contexts: The state of the evidence. London: Overseas Development Institute.

Peters, K., L.E.R. Peters, and C. Walch. 2019b. The Sendai Framework for Disaster Risk Reduction as a vehicle for conflict prevention: Attainable or tenuous? Contributing paper to the Global Assessment Report on Disaster Risk Reduction 2019. New York: United Nations. https://www.undrr.org/publication/ sendai-framework-disaster-risk-reduction-vehicle-conflict-pre vention-attainable-or. Accessed 29 June 2020.

Peters, K., L.E.R. Peters, C. Walch, and J. Twigg. 2019c. Disaster risk reduction strategies: Navigating conflict contexts. London: Overseas Development Institute.

Peters, K., L. Mayhew, O. Borodyna, H. Measures, K. Petrova, C. Nicoson, P. Nordqvist, and L.E.R. Peters. 2020. Climate change, conflict and security scan: December 2018-March 2019. London: Overseas Development Institute.

Platt, R.H. 1999. Disasters and democracy: The politics of extreme natural events. Washington, DC: Island Press.

Quarantelli, E.L. 1954. The nature and conditions of panic. American Journal of Sociology 60(3): 267-275.

Quarantelli, E.L. 1987. Disaster studies: An analysis of the social historical factors affecting the development of research in the area. International Journal of Mass Emergencies and Disasters 5(3): 285-310.

Quarantelli, E.L., and R.R. Dynes. 1976. Community conflict: Its absence and presence in natural disasters. Mass Emergencies 1: 139-152.

Rajagopalan, S. 2006. Silver linings: Natural disasters, international relations and political change in South Asia, 2004-5. Defense \& Security Analysis 22(4): 451-468.

Raleigh, C., and D. Kniveton. 2012. Come rain or shine: An analysis of conflict and climate variability in East Africa. Journal of Peace Research 49(1): 51-64.

Régnier, P. 2011. The emerging concept of humanitarian diplomacy: Identification of a community of practice and prospects for international recognition. International Review of the Red Cross 93(884): 1211-1237.

Reimann, C. 2004. Assessing the state-of-the-art in conflict transformation. In Transforming ethnopolitical conflict: The Berghof handbook, ed. A. Austin, M. Fischer, and N. Ropers, 41-66. Wiesbaden: Springer-Verlag.

Reuveny, R. 2007. Climate change induced migration and violent conflict. Political Geography 26(6): 656-673.

Sachs, J.D. 2007. Poverty and environmental stress fuel Darfur crisis. Nature 449(7158): Article 24.

Sakaguchi, K., A. Varughese, and G. Auld. 2017. Climate wars? A systematic review of empirical analyses on the links between climate change and violent conflict. International Studies Review 19(4): 622-645.

Salehyan, I. 2014. Climate change and conflict: Making sense of disparate findings. Political Geography 43: 1-5.

Salehyan, I., and C.S. Hendrix. 2014. Climate shocks and political violence. Global Environmental Change 28: 239-250.

Sarmiento, J.P., V. Sandoval, M. Jerath, G. Hoberman, A. Arrieta, W. Chen, M. Lidth de Jeude, O. Schütte, et al. 2018. Performance evaluation in LAC urban DRR programming: The neighborhood approach. Washington, DC: United States Agency for International Development.

Scanlon, J. 2006. Dealing with the tsunami dead: Unprecedented international co-operation. Australian Journal of Emergency Management 21(2): 57-61. 
Scheffran, J., M. Brzoska, J. Kominek, P.M. Link, and J. Schilling. 2012a. Climate change and violent conflict. Science 336(6083): 869-871.

Scheffran, J., M. Brzoska, J. Kominek, P.M. Link, and J. Schilling. 2012b. Disentangling the climate-conflict nexus: Empirical and theoretical assessment of vulnerabilities and pathways. Review of European Studies 4(5): 1-13.

Schleussner, C.F., J.F. Donges, R.V. Donner, and H.J. Schellnhuber. 2016. Armed-conflict risks enhanced by climate-related disasters in ethnically fractionalized countries. Proceedings of the National Academy of Sciences 113(33): 9216-9221.

Schneider, F., and Y.J. Hwang. 2014. The Sichuan Earthquake and the Heavenly Mandate: Legitimizing Chinese rule through disaster discourse. Journal of Contemporary China 23(88): 636-656.

Selby, J., O.S. Dahi, C. Fröhlich, and M. Hulme. 2017. Climate change and the Syrian civil war revisited. Political Geography 60: 232-244.

Seybolt, T.B. 1996. The myth of neutrality. Peace Review 8(4): 521-527.

Slettebak, R.T. 2012. Don't blame the weather! Climate-related natural disasters and civil conflict. Journal of Peace Research 49(1): 163-176.

Theisen, O.M., N.P. Gleditsch, and H. Buhaug. 2013. Is climate change a driver of armed conflict? Climatic Change 117(3): $613-625$

UNDP (United Nations Development Programme). 2011. Disasterconflict interface: Comparative experiences. New York: Bureau for Crisis Prevention and Recovery, UNDP.

UNISDR (United Nations International Strategy for Disaster Reduction). 2005. Hyogo framework for action 2005-2015: Building the resilience of nations and communities to disasters. Geneva: UNISDR.

UNISDR (United Nations International Strategy for Disaster Reduction). 2015. Sendai framework for disaster risk reduction 20152030. Geneva: UNISDR.
UNDRR (United Nations Office for Disaster Risk Reduction). 2019. Global assessment report on disaster risk reduction. Geneva: United Nations.

Väyrynen, R. 1991. New directions in conflict theory: Conflict resolution and conflict transformation. London and Newbury Park, CA: Sage Publications.

Venugopal, R., and S. Yasir. 2017. The politics of natural disasters in protracted conflict: The 2014 flood in Kashmir. Oxford Development Studies 45(4): 424-442.

Verhoeven, H. 2011. Climate change, conflict and development in Sudan: Global neo-Malthusian narratives and local power struggles. Development and Change 42(3): 679-707.

von Uexkull, N., M. Croicu, H. Fjelde, and H. Buhaug. 2016. Civil conflict sensitivity to growing-season drought. Proceedings of the National Academy of Sciences 113(44): 12391-12396.

Wanis-St. John, A. 2005. Cultural pathways in negotiation and conflict management. In The Handbook of dispute resolution, ed. M.L. Moffitt, and R.C. Bordone, 118-134. San Francisco: Jossey Bass.

Watts, M. 1983. Silent violence: Food, famine and peasantry in northern Nigeria. Berkeley, CA: University of California Press.

Wisner, B., P. Blaikie, T. Cannon, and I. Davis. 2004. At risk: Natural hazards, people's vulnerability and disasters, 2nd edn. London: Routledge.

Wolf, A.T., S.B. Yoffe, and M. Giordano. 2003. International waters: Identifying basins at risk. Water policy 5(1): 29-60.

Wood, R.M., and T.M. Wright. 2016. Responding to catastrophe: Repression dynamics following rapid-onset natural disasters. Journal of Conflict Resolution 60(8): 1446-1472.

World Economic Forum. 2019. UN Secretary-General: Fragmented response to global risk a 'recipe for disaster.' https://www. weforum.org/press/2019/01/un-secretary-general-fragmentedresponse-to-global-risk-a-recipe-for-disaster/. Accessed 16 April 2020.

Xu, J., Z. Wang, F. Shen, C. Ouyang, and Y. Tu. 2016. Natural disasters and social conflict: A systematic literature review. International Journal of Disaster Risk Reduction 17: 38-48. 